\title{
Torsten Hagerstrands time-geography as the cradle of the activity approach in transport geography
}

Kajsa Ellegård and Uno Svedin

\section{Linköping University Post Print}

N.B.: When citing this work, cite the original article.

Original Publication:

Kajsa Ellegård and Uno Svedin, Torsten Hagerstrands time-geography as the cradle of the activity approach in transport geography, 2012, Journal of Transport Geography, (23), 17-25. http://dx.doi.org/10.1016/j.jtrangeo.2012.03.023

Copyright: Elsevier http://www.elsevier.com/

Postprint available at: Linköping University Electronic Press

http://urn.kb.se/resolve?urn=urn:nbn:se:liu:diva-79680 


\section{Torsten Hägerstrand's time-geography as cradle of the activity approach in transport geography}

\section{Abstract}

The aim of this article is to put Torsten Hägerstrand's contribution to the development of the activity approach in transport geography into the context of his development of time-geography as an integrative ecological world view. This is discussed from a biographical perspective where experiences in his everyday life and scientific investigations are linked into a theoretical whole. The theoretical approach of Hägerstrand can be traced to experiences several years before he presented his time-geographic approach. He studied conditions for individuals' existence in different geographic, social, and ecological contexts by engaging new methods and cross-fertilizing research fields; he developed precise concepts and a notation system general enough to describe any kind of individual and applicable at different levels of aggregation. He combined theoretical and methodological developments in science with active involvement in the Swedish planning model in various sectors, not least urban and transport planning - at the same time as he criticized the fragmentation of society into separate sectors for policy and planning purposes. The article shows that Hägerstrand's early sources of inspiration were in his struggle to develop both a precise and general time-geographic approach. The activity approach in transport research is ingrained in time-geography since the extension of and distance between locations of resources make transport inevitable. Hence, the human needs of transport are generated from activities in people's everyday lives. Hägerstrand's activity approach was developed in an era when transport prognoses based on the development of demand for transportation as such prevailed. Today, the activity approach is a dominant strand in transportation research.

\section{Introduction}

Professor Torsten Hägerstrand was a modern geographer fostered in the old school of regional geography, with its holistic perspective on the interdependence of nature and mankind across regions. He argued that geographers should contribute to make the Earth a sustainable home for its various populations and to help people understand not only the promise of new technologies, but also the threat, for example, to resources and life forms. He urged geographers to take on an integrative task rather than simply combining geographical phenomena - and to "restore the links and reestablish a balance between the biophysical and the human branches of geography which are now mostly carrying on their business widely separated from each other" (Hägerstrand, 1976, p. 330). He advanced the view that human industrial activities affect land, water, and the life of many species, and gave examples of chemical substances that can be found not only where they are intended to be, but also in many other places and parts of ecosystems where they are not supposed to be. He claimed, "It is more and more clear that mankind has become a geological agent" (Hägerstrand 1993b, p. 161). He 
seldom, however, used the term holistic and preferred the term ecologic, which marks the real-world base of his geographical understanding. Hägerstrand wanted to stress the importance of the material aspects of the real world as the basis of life, with an imperative for researchers to take basic constraints into consideration: that natural resources, time, and space are limited - just like the life of an individual. He pointed out that a weakness with non-materially grounded thinking about problems in the real world might lead to decisions that do not sufficiently consider factors that are deeply embedded in everyday thinking and therefore left out. He stated “... that it is very easy to dream up blue-prints for new undertakings but very hard to imagine their fate and their consequences for other legitimate processes when put into practice. Perhaps the trouble is that thought does not encounter in its own world the constraints of space and time" (Hägerstrand, 1976, p. 334). Hence, he opposed the translation of natural and other resources into economic values as a single basis for decision, since then the material substance of a resource and the distance between the geographical location of its origin and the location of its use were hidden. He wrote, "A world without extension is not a possible world" (Hägerstrand 1991, p. 161). Thereby, he also pointed to the inevitability of distance and, consequently, the necessity of transportation.

Nevertheless, Torsten Hägerstrand was not a hard-core materialist. His materialism is embedded in a deep concern for the importance of human experiences, reflections, and reasoning for the development of geographical knowledge. This becomes clear when one reads more deeply into his sources of inspiration in autobiographical texts (as in Hägerstrand, 1982, 1983), into books in his personal library and into the citations he wrote by hand on small sheets of paper from the multitude of readings that he sorted into boxes with themes to serve as inspiration for his future writings. ${ }^{1}$

The aim of this article is to put the important contribution to the development of the activity approach in transport geography made by Torsten Hägerstrand into the context of his development of timegeography as an integrative ecological research approach. This is discussed from a biographical perspective where experiences in his everyday life and scientific investigations are merged into a theoretical whole - i.e., time-geography as an expression of his ecological world view. Two intriguing things about the theoretical development of Torsten Hägerstrand are, first, that it can be traced to experiences several years before he presented his time-geographic approach and, second, that, in his last major work and intellectual testament The Fabric of Existence (2009), ${ }^{2}$ he did not use the term time-geography even though the book as such is an exposé of his time-geographic concepts and its notation system - albeit with focus on the ecological world view.

\footnotetext{
${ }^{1}$ Some books and examples of his boxes of citations have been collected, in accordance with his own will, in the Hägerstrand room at the Department of Thematic Studies, Linköping University, Sweden.

${ }^{2}$ The book is in Swedish and the Swedish title is Tillvaroväven.
} 
In the second section of this article, we offer a short biography of Professor Torsten Hägerstrand and indicate some sources of inspiration emanating from his childhood and early university studies. The third section presents the ecological world view that Torsten Hägerstrand presented piece-by-piece over a long period of time. We briefly present time-geographical concepts and the notation system that emanated from his amalgamating experiences from the academy and everyday life into a whole, coherent ecological world view. In the fourth section, his influence on transportation geography is discussed. The final section provides concluding remarks.

\section{Torsten Hägerstrand in his life context}

\subsection{A short biography}

Torsten Hägerstrand (1916-2004) is one of the most internationally renowned Swedish researchers in social science of the last half-century (Lenntorp, 2004). He was Professor in Human Geography at Lund University between 1957 and 1972, at which time he was awarded a personal chair by the Swedish Research Council for the Humanities and Social Sciences, a position he held until his retirement in 1982. A study of the influence of Torsten Hägerstrand on the scientific community from the late 1950s until 2008 shows that his cited articles are clustered into three main research themes: innovation, migration and activity, travel and space. He is frequently cited from the late 1960s onwards at a frequency of about 20 to 40 articles per year, and there is a considerable increase during the years after his death, peaking at 65 articles (Persson and Ellegård, in press). Hägerstrand continued as an active senior researcher and appreciated discussion partners until his last days.

Hägerstrand's influence, however, is not limited to scientific endeavors. His way of analyzing, his methods, and the results of his research all had a substantial impact on societal planning. For example, he actively engaged in the government project led by Swedish minister Alva Myrdal on future research (Hägerstrand, 1972). The breadth and depth of Hägerstrand's work is impressive and points to a normative mission for scientists from natural, social, and technical sciences to learn from each other, to cooperate, and to develop integrated approaches in order to create opportunities for a sustainable use of our common world (Hägerstrand and Lenntorp, 1974; Hägerstrand and Lenntorp, 1993). The combination and integration of ecological, economic, and social aspects - including studies of behavior based on habits - provides a deeper understanding of the interrelations influencing life in the landscape. Hägerstrand presented his ecological approach to politicians and scientists at a conference in January 1977, where he defined the problem of how to understand the contexts of the human world (Hägerstrand, 1977). He argued for a definition of the concept of ecology broader than the merely biological one dominant at that time. He acknowledged the biological approach, but wanted to include the human influence as it is expressed in societies, and he highlighted the motives for human projects and people's daily activities (Hägerstrand, 1977; 1993a). 
Hägerstrand's last major piece of writing on which he was still working in his final days ${ }^{3}$ clearly states the broad ecological approach he advocated, as does one of his last articles (Hägerstrand, 2004).

\subsection{Childhood as source of inspiration}

Torsten Hägerstrand grew up as the son of the local schoolteacher in the small village of Torpsbruk, in Moheda municipality in the county of Småland situated in the south of Sweden (Hägerstrand, 1983; Carlestam and Sollbe, 1991). Forestry and small agriculture dominated the area, and as he grew up the number of other small-scale industries was increasing. The schoolhouse where his family and his classroom were located, provided, together with the schoolyard, his first local geographical and ecological context (Hägerstrand, 1982; 1983). In the schoolyard, he was inspired and gained knowledge about how species of different kinds coexisted side-by-side in one place: man-made artifacts (for example, buildings, tools, and toys) and nature (including animals like butterflies, plants, and birds, as well as stones) occupied and utilized the schoolyard space in different ways and in a daily rhythm given by the presence or absence of the school children. Together, the different kinds of species occupying space in the schoolyard provided opportunities for the children's play and learning. Some of them also served as the teacher's examples of how nature can be utilized for human sustenance. Taken together, they can be regarded as place-bound resources at the same time as they appear as restrictions constraining children's activities. The recently established school subject Hembygdskunskap ${ }^{4}$ (inspired by the didactic writings of the Swiss pedagogue Pestalozzi) was eagerly taught by the schoolmaster, Hägerstrand's father. His efforts to grasp the whole by integrating the various species occupying the same piece of land by starting from the simple and moving to the more complex, established the ground for a long-standing line of thought for the boy (Carlestam and Sollbe, 1991, p. 206).

Life in the small village, the contact with animals at the surrounding small farms, and the experience of nature in the forests served as the basis for the young boy's understanding of the world (Hägerstrand, 1982). As years went by, his reach widened and he took note of how different functions in the farms depended on the knowledge, skills, and different resources of the environment, providing subsistence for people through their work in the fields and forests (Hägerstrand, 1984). His curiosity and personal experiences provided a base for his analytical thinking about how the world might be organized and how the landscape as a coherent whole could be understood.

2.3 Clashes in the encounter of higher education

\footnotetext{
${ }^{3}$ The book was not totally completed before his death, and the final edit was performed by the authors of this article.

${ }^{4}$ Hägerstrand translated it into English as "home-area study” (Hägerstrand, 1983).
} 
As the schoolmaster's son, who was constantly expanding his interests in geography and local history, Hägerstrand absorbed at an early age the importance of education, scholarly knowledge, and theories to understanding how the resources of the earth could (or ought to) be distributed and used in an ecological, sustainable way. As a student in Lund, Hägerstrand became increasingly dismayed to find that scholarly knowledge seemed to aim at collecting, sorting, and classifying all the different phenomena of the world within the closed shops of disciplinary organization, while the integrative task of grasping and analyzing the whole context of real life in which difference and variation play a central role was neglected (Hägerstrand, 1976). Especially, he was uneasy about the situation in which the specialists of science (in its broadest connotation) did not seem to exchange knowledge among each other; instead, each aimed to accumulate individual professional merits by striving to understand some particular phenomenon in their specialty. This meant a delay in any possible development aimed at better grasping totalities, including how various human and animal individuals operate in the world of material phenomena. These kinds of problems were of high interest to Torsten Hägerstrand throughout his life.

\subsection{A formative research task}

One of the first research tasks Hägerstrand was assigned as a $\mathrm{PhD}$ student in geography dealt with what happened to small farms and the population in local areas that were left behind when the great wave of emigration from Sweden to the United States took place in the end of the 19th century. His professor, Helge Nelson, gave him this task as part of a larger initiative to write a regional geography of Southern Sweden (Hägerstrand, 1983). The results of Hägerstrand's work attracted great attention in the scientific community. His method combined the documentary study of population changes from official church records and excursions by bike giving him personal first-hand experience and study of the characteristics of the landscape. The field work was done together with his then-fiancée and later wife Britt Hägerstrand.

Torsten Hägerstrand's investigations in this initial work in the area of emigration led to a new understanding of movement patterns in a population (Hägerstrand, 1950, 1962, 1982). He traced the steps of persons who had moved from one small farm to another to improve their livelihood. One conclusion drawn from this early research challenged the prevailing scientific opinion that emigrants had left from abandoned farms in the landscape. On the contrary, by combining empirical landscape studies of farming conditions and the examination of church records on emigrants, he showed that the abandoned farms lay on marginal, less fertile land, and that the emigrants had left, not from these places, but from farms located in areas with better farming conditions. These better-off farms had been sold by the emigrants, and people from poorer conditions were then able to move into them. Hägerstrand's approach - following the paths of individuals from place to place over time, revealed that people's life histories could be described as a sequence of movements, i.e., a sort of movement 
chain. Within this perspective, he coined concepts like prime movement, stations, and replacement movements (Hägerstrand, 1962). This was then a new approach in geographical research.

The studies of emigration areas in Sweden made clearer the importance of earlier events in individuals' lives in understanding a later situation, providing in turn the context for still more recent events or chains of events. These empirical studies also inspired Hägerstrand to do the research he presented in his influential thesis Innovation Diffusion as a Spatial Process,${ }^{5}$ published in Swedish (Hägerstrand, 1953). Hägerstrand's lines of thought on movement chains and innovation diffusion were further woven together in his creation of the ecological time-geographical approach that became the mark of much of his contribution to the scholarly world (Hägerstrand, 1993a). Hägerstrand introduced the activity approach in transportation research in the 1960s and his writings were initially frequently cited. There was a dip in citations in this field during the 1980s. However, after the introduction of more effective computer technology, there was a surge in citations to Hägerstrand in transportation research again in the 1990s (Kwan, 2004; Persson and Ellegård, in press).

2.5 Music and the time-geographical notation system

Handicraft, i.e., the craft of the hand and more generally the use of the hand, in its widest sense was one of the domains of inspiration for Hägerstrand. Another important domain was music (Hägerstrand, 1983). In his childhood he got used to the technical side of this endeavor, helping his older brother turn the pages as he played the organ. Hägerstrand was also given the task of foot-pumping the stream of air to the organ pipes. As a reward for all this, he was introduced to the art of organ playing and learned how to read and interpret the notes. This activity yielded the insight that individual marks on paper could be transformed into tones from an instrument; he learned how to read the sounds of music. Translation from a musical notation system into instrumental music may be regarded as an early source of inspiration to his later efforts to develop a notation system for his time-geography, the interpretation of which extends beyond its mere visual form (Hägerstrand, 1985). Time-geographical concepts relate to a time-geographical notation system and resemble notes in the musical notation system. Hägerstrand expanded his reasoning in various ways within geography by using metaphors drawn from music terminology, such as the score (Sw. partitur), the coloring of a tone (Sw. klangfärg) and chord (Sw. ackord) (Hägerstrand, 1978). Music, handicraft, and agriculture are areas that demand certain knowledge about connections, and the production of a song, a sweater, or a good harvest are the results of a performer's interpretations of an idea about what constitutes a whole and the skills required to materialize it.

2.6 Ecological time-space inspiration: from geese flights to GIS

\footnotetext{
${ }^{5}$ The original title in Swedish is Innovationsförloppet ur korologisk synpunkt (Hägerstrand, 1967). It was translated into English in 1967 by the American geographer Allan Pred.
} 
As a young boy, Hägerstrand read The Wonderful Adventures of Nils by Selma Lagerlöf (1906/07), ${ }^{6}$ later a Nobel Prize winner in literature. The book was written with the intention of producing a reader in geography for schoolchildren. The main character is Nils Holgersson, a boy who has been shrunken in size and rides on the back of a big goose flying in the spring from Southern Sweden to the North. From above, he views the rolling totality of the landscape. As he flies above Sweden, he learns not only geography, but also history and social relations. Perhaps as he read this book, Hägerstrand was already becoming inspired to identify the basic importance of making the dimensions of time and space visible in order to explain chains of events and patterns - what happens when individuals from different types of populations (human, animal, artifact, natural) coexist and exert power over each other in the landscape.

Selma Lagerlöf wrote the story of Nils Holgersson after she traveled widely in Sweden and used all her senses to get acquainted with nature, the culture, the people, and historically important places. She was inspired by people who in different ways had themselves been framed by the landscape in which they lived - and from which they earned their living. From the back of the goose, Nils sees the landscape from above from a perspective in which spectacular natural panoramas and big buildings seem small and limited. But since Nils is a tiny, small character, he also had to see the world from below - through the perspective of the underdog with limited means. In the beginning of the book, before he was shrunk, Nils was not a very considerate type of person; he was lazy and mean. But through his experiences with the geese and widened perspectives both from above and below, Nils gradually developed a broader view and grew and matured in his understanding of social relations and about the relation between humans and nature, that is, ecology in a broad sense. Perhaps the double perspective from below and from above ${ }^{7}$ inspired Hägerstrand in his development of the postulates for time-geography, especially the need for opportunities within the time-geographic approach to move from micro to macro level without losing important information (Hägerstrand, 1974). Perhaps the experiences at the individual level compared against the distanced perspective from above, inspired Hägerstrand to the development of the general, naked way to describe the different kinds of phenomena that characterize some of the concepts and the notation system of time-geography.

Sometimes in the story, Nils strays and loses contact with his group of geese just because he and they have not made sufficiently clear where to meet after looking for food in separate places. When the geese are about to emit warnings about emerging dangers, they need information about places

\footnotetext{
${ }^{6}$ The Swedish title is Nils Holgerssons underbara resa genom Sverige, first published in 1906/07. Translated by Velma Swanston Howard. Illustrated by H. Baumhauer (1960) or Thea Kliros (1995). Published in 1910 by Bird, London. 4th printing in 1961 by Pantheon, New York. Reprinted in 1966 and 1984 by J.M. Dent \& Sons, London. Published in 1995 by Dover, New York.

${ }^{7}$ This double perspective, from below and from above, that Lagerlöf creates is also considered by Crang (2000).
} 
providing food or protection while they pause for relaxation - that is, navigation instructions. In this way, Selma Lagerlöf illustrates the importance of ordering processes in space and time, precisely enough to transmit important messages on location in time-space. In Hägerstrand's time-geography, the sequential and geographical order is especially fundamental.

Through Nils' journey, many generations of Swedish children have gained insights into the various living conditions of people, and enjoyed glimpses of nature and animal life. Readers get an inclusive view of Sweden as a whole, within which they upgrade their understanding of how the country has been historically woven together by events and processes in society and nature, albeit through a blend of fairy tale and more serious historical narrative. This weaving might have served as one early source of inspiration for Hägerstrand's integrative, ecological approach.

The landmarks of buildings and natural formations in the landscape described by Nils' imaginary flight might be regarded as one source of inspiration for Hägerstrand's early idea to assign coordinates to buildings and land (Hägerstrand, 1955). Thereby, he laid the foundation of automated geographical information systems (GIS) long before computers had been introduced into service for tasks like land measurement, geographical positioning, or, more recently, GPS navigation systems (Rystedt, 2005).

\subsection{Air traffic - new technology and risk}

The expansion of air transport boomed during the 1960s and travel between countries worldwide became available to ordinary people. The Princess of Monaco wanted Torsten Hägerstrand to analyze what the expansion of airplane travel could mean for the distribution of contagious diseases and thus the potential explosion of pandemics, i.e., the global spread of disease. However, for what Hägerstrand regarded as political reasons, this study was never performed (Carlestam and Sollbe, 1991). Perhaps such a study, highlighting the risks that might exist in the connections between the technological development of air transport, the increased availability for the many to use the technology, and the possible spread of harmful microorganisms, was too threatening to the emerging passenger air transport sector. Possibly, it was that sheer power aspect of the matter that prevented further exploration of air transport and risk of pandemics in the early phase of universal access to air travel. For example, the outbreak and spread of SARS and "swine flu" more recently, both closely connected to the air travel system, have indicated the importance of studying this phenomenon. Peter Haggett dedicated his book The Geographical Structure of Epidemics (2000) to Torsten Hägerstrand. The book is a late follower of Torsten Hägerstrand's dissertation; Hägerstrand inspired and encouraged Haggett to write about diffusion waves of diseases. In a chapter on the collapse of space, the role of airborne transportation in the diffusion of diseases is specifically discussed (Haggett, 2000).

2 Time-geography - grounding for an ecological world view 
3.1 Concepts and notation system developed for the time-geographical understanding of interaction in the landscape

The time-geographical approach provides a multidimensional and abstract view of the world in terms of processes in the time-space by following individuals from different kinds of populations through events and processes at various places. Within time-geography, Hägerstrand developed concepts and a notation system to communicate time-space processes and thereby to describe and analyze developments over time in geographic space.

Hägerstrand's time-geographic concepts relate to how and why individuals, in one or more populations, link to each other and move (or are moved) between places which are the cornerstones of transport research.

In Hägerstrand's time-geographical terms, different individuals (also denoted as grains in Hägerstrand, 1985) belonging to different types of populations are in touch with each other at a geographical place over time, thus filling the landscape in all its variety. They encounter each other and stay together at a place for a while, and they leave each other and the place. Non-living individuals are moved by living individuals, by artifacts, or by natural forces. The landscape is, from this perspective, occupied by many populations - not only human. Hägerstrand hereby also recognizes an implicit power relation: "The room-occupation and duration of one grain establish boundaries over which other grains cannot move without causing some sort of transformation to occur" (Hägerstrand, 1985, p. 196).

There are intentions and ideas behind many human movements in time-space. Human individuals formulate and pursue projects for their livelihood and pleasure. Projects are performed in different environments and are on different scales. ${ }^{8}$ Some projects claim couplings (between human and/or nonhuman individuals at a place or on the move). A bounded area designed for one or more reoccurring projects is called a pocket of local order, in which the order is agreed upon and upheld by the individuals involved in the project(s) $)^{9}$ (Hägerstrand, 1985).

The fundamental concept of Hägerstrand's time-geographic notation system, with its basic time-space dimensions is the individual path ${ }^{10}$ by which an individual's movements in the time-space are tracked (Hägerstrand, 1970, 1985, 2009). The individual is an undivided entity, a continuant, which is born, produced, or created, and it exists for a time period and thereafter dies, is destroyed or dissolved. The

\footnotetext{
${ }^{8}$ Hägerstrand (1985, p. 201) used the examples writing a letter and organizing a general election.

${ }^{9}$ Pocket of local order is close to what Giddens, with reference to Hägerstrand, called locale (Giddens, 1984, p. 118).

${ }^{10}$ Hägerstrand uses the two concepts individual path and trajectory as synonyms.
} 
individual path is the key to understanding many of Hägerstrand's conceptual constructions and notation system.

Indivisibleness $\left(\mathrm{Sw}\right.$. odelbarhet ${ }^{11}$ ) is the fundamental basis of all individuals as they are defined in their time-space existence over a time period. Hence, each human and animal constitutes an indivisible individual from birth to death. In an early work, Hägerstrand used the concept of finitude to mark this (Hägerstrand, 1976). Artifacts are products created by living individuals combining ideas, skills, and raw materials into functioning material things; products exist as non-living individuals until they are destroyed. An artifact is defined as an individual from its creation to its destruction. There is an embedded process of change in the concept since before they are born/created, the individuals are parts of earlier individuals (parents or raw materials).

In the notation system, elementary events (Sw. elementarhändelse) are used to describe what happens to individuals moving in the time-space, and these events can be used to study production processes as well as innovation processes and everyday life. The elementary events are embedded in the very constitution of time-geographic thought, but they are not presented in a coherent way until Hägerstrand's final book in 2009. Some important elementary events repeatedly appear during the life of an individual as it is described by the individual path: encounter (Sw. påträffande), which stands for a part of the individual path in which it is about to meet a path of another individual and thus lay the ground for the two to get in touch (Sw. beröring), which illustrates individuals being together at a place or on the move, side-by-side-ness (Sw. bredvidvartannathet), which puts to the fore one of the most overlooked characteristics of individuals' existence: being together at a place for a time period in an earlier text this was denoted as coupling (Hägerstrand, 1985). The latter elementary event also relates to the fact that individuals cannot overlap in time and space due to their materiality. The concepts side-by-side-ness and before-and-after-ness are closely connected, where the former relates to place/location and the latter to time (sequence) (Hägerstrand, 1985). Individuals encountering, getting in touch, and for a while existing side-by-side will after some time part (Sw. åtskiljas) from each other, either one or both of them leaving the place where they got in touch (Hägerstrand, 2009).

The elementary event be-in-place-ness ( $\mathrm{Sw}$. stationär fortvaro) illustrates that an individual exists over time while he/she/it is located at the same place for a time period, and, consequently, from a transport perspective, nothing happens, since there is no geographical movement. But there is a movement in time, and since most individuals spend more time by being-in-place than being on the move (Eurostat, 2003), this concept is important.

\footnotetext{
${ }^{11}$ A few examples of the types of concepts Torsten Hägerstrand designed and used are given here after being translated into English, while acknowledging that his linguistically novel constructions in Swedish emerge from his close relation to his mother tongue, making the translation a challenge similar to translating poetry.
} 
The front line of the fabric (Sw. vävfront) is one of Hägerstrand's later constructs (Hägerstrand, 2009). It brings to the fore what geographical locations various individuals have at the point in time called now. Now is, in a time-geographical sense, at the same time the constant present and the steadily ongoing transformation of future to past. Now is, then, the only window of opportunity for change. The metaphoric concept front line of the fabric indicates that the process of weaving the fabric of existence is ever ongoing where human individuals pursue their projects and create and utilize individuals from other populations for their human purposes. (See Figure 1 for some time-geographic elementary events.)

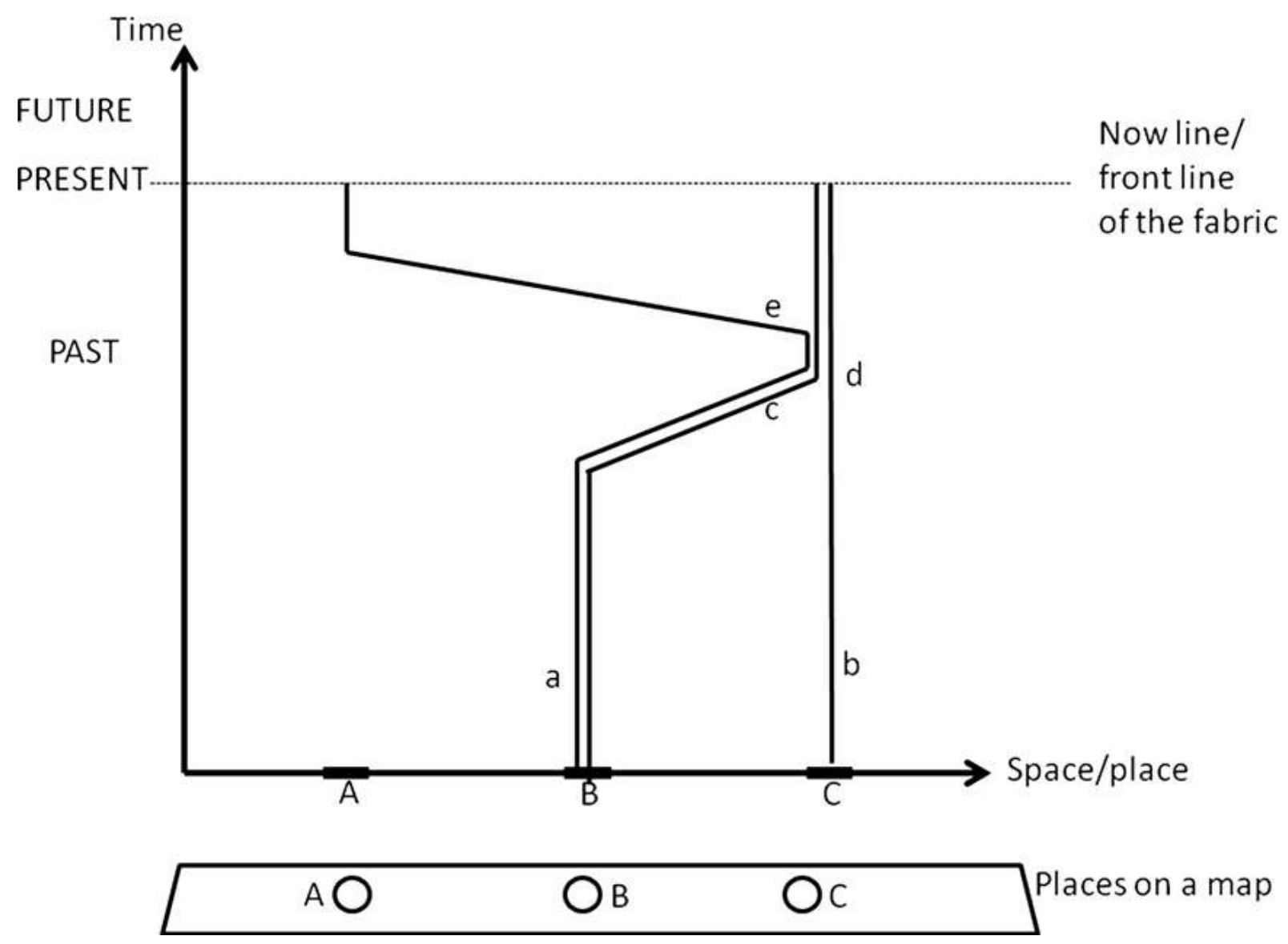

Figure 1. The time-space simplified to two dimensions. Three individual paths from the past are depicted, and some elementary events are illustrated by the paths: (a) side-byside-ness, (b) in-place-ness, (c) encounter, (d) touch, (e) separate. Just one of each kind of elementary event has the legend attached to it even though there are more occasions when the elementary events appear. The front line of the fabric is illustrated by the time-space location of the individual paths Now. In principle there is a prism starting at the front line of the fabric (see Section 4.2) for each individual, however not shown in the figure.

The concepts are developed over time, first the basic ones (such as individual, path, population, project, pocket of local order) which can be regarded as the most important tools for getting deeper into the time-geographic thinking and ecological world view (Hägerstrand, 1970; 1985). Later these concepts are put into a larger context, aiming at increasing the understanding of how to, in an 
ecological and sustainable way, utilize and develop the Earth as home and resource for life (Hägerstrand, 2009).

If implemented into actions, human projects driven by visions about the future can either lead astray and even into various collapses and disasters or, at best, they can lead to a sustainable development in all its dimensions. The concepts and thinking of Hägerstrand provide us with tools for analysis, grounding for making choices and insightful action. Some of the concepts may at a first glance seem trivial because they are so close to everyday life experiences that they may seem not scientifically relevant. This might obstruct the identification of their theoretical potential, especially for those using theoretical concepts designed at some distance from everyday world reality, for example, in terms of their abstractness. Hägerstand's concepts and notation system help to highlight phenomena that we need to see in order to think ecologically, irrespective of whether these phenomena are perceived to be self-evident as an outflow of everyday knowledge or if they are distinctly new (Hägerstrand, 1984). In his final book, Hägerstrand returns to Husserl's concept of Gesamtraum (Eng. space-for-all, Sw. allrum) to underline that all individuals of various populations share the Earth's crust, water, and air with each other (Hägerstrand 2009, p. 84).

Even though the concepts have developed over time, we claim that the line of thought in Torsten Hägerstrand's time-geography stays consistent. The basic concepts from the 1960s and 1970s are in his later work embedded into one coherent philosophical world view in which new concepts, with a closer connection to ecology, are also introduced. Those of us who have had the advantage to follow his work know how he struggled to find concepts congruent with his thinking.

\subsection{An approach with a strong ontology}

Hägerstrand's final work The Fabric of Existence (2009) contains the thought lines he had dwelt upon over decades. The book takes as its starting point ecologically oriented perspectives, but also includes other lines of thought. In ecology, respect is evident for the long-term perspective, as well as for the limited availability of natural resources. But other phenomena of almost self-evident nature are made transparent and clear as the sheer fact that the time of existence for living creatures - including humans - is limited. This also holds true, Hägerstrand stressed, for the space available for agriculture on this planet. For those who lived in earlier historical eras, such things were regarded as self-evident: there was the land, the sun, and the rain that served as resources for growing crops and breeding animal livestock. Absence of rain was a restriction of farming - and thereby of life. But for later generations, these understandings became hidden as the differentiation between production and consumption in the industrial and, even more, postindustrial society became more pronounced (Hägerstrand, 1984). Nature is, in the industrialized mindset, looked upon more as an unlimited source of resources to exploit. Hägerstrand worried about it. He wrote, "It is as if our well-developed capacity 
to store and hold together systems of ideas makes us unable intuitively to feel the limitations of the external world to accommodate our projects." (Hägerstrand, 1985, p. 216).

Despite the concepts based in everyday life experiences, the world view of Hägerstrand as expressed in his texts invites the readers to think thoughts that from the beginning might seem a bit odd. One such perspective stresses the approach that humans - in certain aspects of application - should be regarded in the same way as we regard other living creatures, i.e., as individuals that occupy space and that use different kinds of resources all through their lives. Such a perspective may seem reductionist and materialistic, but when the argumentation is followed through, it provides a basis for an argument for human responsibility and for sustainable development. Hägerstrand's ultimate aim was to facilitate the understanding of why societal action and use of natural resources both at the limited micro level and in our common existence in the world as a whole should be sustainable. He identified a need for concepts that can be used at all levels (Hägerstrand, 1974; 2004).

Hägerstrand's efforts to help us understand interlinked natural and socio-technical phenomena, especially in their interplay with the world of humans, are demonstrated in his last book (Hägerstrand, 2009). In such a broad field, it is a challenge to create theories with a similar degree of explanatory power as is sometimes generated in more specialized disciplines. Hägerstrand's aim, and his provisional solution, was to provide an investigative tool probing both the breadth and depth of phenomena by outlining the restrictions that humans have to adapt to in order to live their lives and make their choices within them. One such restriction, that he constantly returns to and which is one of the cornerstones in all his approaches, is that all individuals are located in the time-space. The timespace is often, for the sake of didactic simplicity, reduced to two dimensions, as in Figure 1. The simplification helps outline an argument of reasoning in a particular case. In this context, we want to point to the constant reminder by Hägerstrand of the importance of the physical materiality that characterizes much of our human existence. He worked all his scientific life in opposition to the types of social science in which the material reality is disregarded, or looked upon as so trivial that it is taken for granted, and thus is not included or reflected upon when theories are constructed. As pointed out in the introduction, he was especially concerned about the problems arising in the real world from the economists' reduction of matter to abstract economic value with no geographic location.

Hägerstrand argued that it was important to build bridges between natural and social science and that his contribution was to develop concepts and a world view that researchers from both sides would understand. This would help to spread insights about the ecological base for life and how it could be investigated in a coherent way. Hence, he underlined the importance of how human ideas and values influence people's creation of projects and inform their interpretation of processes and phenomena. From the early 1970s, Hägerstrand had an ongoing dialogue with his scientific collaborator and associate Anne Buttimer, who once said that what he presented by the notation system was a "danse 
macabre" ${ }^{, 12}$ wherein the images and perceptions of time and the bio-ecological rhythms were omitted. In their discussions, Hägerstrand recognized that he had taken for granted the human will, intentions, and experiences behind the individual path describing a human individual. So, he wrote, in his mind the path was not naked (Hägerstrand, 1983, p. 254). ${ }^{13,14}$

Hägerstrand introduced an alternative way to study the range of opportunities people have to realize their projects in the future. Instead of using probability approaches, he created within his timegeographical approach concepts dealing with constraints that limit individuals in their daily activities as they stand at the front line of the fabric. Living individuals are obliged to eat, sleep, and take care of their personal hygiene; most of these activities are performed at home. In addition to these physiologically necessary activities, there are authority, capacity, and coupling constraints (Hägerstrand, 1970; Mårtensson, 1979). Authority constraints concern laws, regulations, and agreements (e.g., employment agreements that regulate the working hours) and are not easily changed. In daily life, authority constraints set the limit for when an individual must be at the workplace or when the grocery store is open for customers. In turn, these time limits constrain the time an individual has left for going to and from the workplace and consequently for being at home and socializing with the rest of the family. They also influence the time slot when children should be picked up from nursery school. A parent picking up a child, thereby taking back responsibility for the child from the nursery school, is an example of how people have to couple themselves together in time-space in order to transfer information or responsibility from one to another, i.e., coupling constraints. Capacity constraints concern the individual's skills, knowledge, material assets, and tools; of course, children are less well off in this respect than most adults. Constraints are important tools, for example, in the study of the everyday life opportunities of families in urban and rural areas to fulfill various projects (Hägerstrand and Lenntorp, 1974).

\footnotetext{
12 "Anne said to me that the worldview depicted in my kind of diagrams reminded her of a danse macabre. I felt a startling flash of light. I was alarmed. My whole effort had for decades been to work towards a holistic view of geography which should be able to catch evolving life." (Hägerstrand, 2006, p. xi).

13 "Not that I believed that living and conscious behavior could be explained in the manner physicists do with their particles. Rather, I feel strongly the need - whatever its roots - to pin down events as to their precise location with respect to space, time and actors before I feel entitled to talk about them. To me much of the explanations current in history and geography, in the social field and even in some branches of the natural sciences, seem very incomplete because of the omission of the temporal and spatial roots of situations." (Hägerstrand, 2006, p. xii).

${ }^{14}$ Hägerstrand and Buttimer also closely collaborated in the jointly initiated "Dialogue project" (Buttimer, 1983, 1986) in which interviews with senior researchers in several disciplines about their own picture of their biography and sources of inspiration were recorded - the result of which now mostly is deposited in the Lund University Library. These demonstrated interests and efforts clearly show the wider non-nakedness perspectives of Hägerstrand.
} 
Constraints refer both to phenomena that have occurred in the past and to the possible paths that can be trodden in the future material world. Torsten Hägerstrand was of course aware of the importance of what immaterial phenomena, like individuals' wants, wills, and values, mean to the projects in which people are involved. To underline this, he incorporated into his representation of the material world a related idea of the immaterial world. Thereby, he actualized the importance of what influences people's doings within the limits set up by the constraints (Hägerstrand, 2009; Lenntorp, 1976; Mårtensson, 1979). Here, Hägerstrand was inspired by the sociologist Alfred Schütz, who argued that overt working results in changes in the outer world, implying that what is done cannot be undone, while covert performance - i.e., thinking about a problem in one's inner world - does not change the outer world, at least not instantly (Hägerstrand, 2009, pp. 162, 238). On the border between the outer, material world and the inner, immaterial world, human individuals have need for transportation to go somewhere else to do something they want to do. Hence, in order to realize (in the material world) their projects (ideas and goals in the immaterial world) people now and then have to move from one location to another.

3 Transportation - means to reach stations for a meaningful daily life

\subsection{Grounds for Hägerstrand's thinking about transportation}

Some circumstances should be kept in mind when dealing with the influence of Torsten Hägerstrand on transportation research. First, he lived his whole life without a driving license. Hence, walking, biking, and public transportation were his main ways to move between places of importance for activities related to work, service, and family projects. Second, the geographical starting point of his life trajectory was located in a region dominated by agriculture and forestry. The population mainly obtained their sustenance from local resources: land, plants, animals, forests, etc. Farmers seldom had to leave their local neighborhood for work or service. Hägerstrand theorized about livelihoods of this kind in an article, calling this type of societal organization a vertically linked society (Hägerstrand, 1965). In this article, he also followed the societal and technological developments of the first half of the twentieth century and called the result of these processes a horizontally linked society, wherein modern industries send raw materials, intermediate goods, final products, and employees all around the world to reach global consumer markets (Hägerstrand, 1965). Later, Hägerstrand related the development and strengthening of horizontal links to differences in power attributed to different places and to transportation: "Speedy vehicles tend to strengthen political and economic hierarchies in favor of the centers and at the expense of the peripheries" (Hägerstrand 1985, p. 213). Third, he argued, when individuals' movements in time and space are studied, one must also consider what happens when people are stationary (i.e., there is only movement in time). Hence, time goes on while the person does something while staying at the same location for a time period (elementary event: be-inplace-ness). The usual focus in transportation research at that time was geographical movement 
between places (i.e., movement in space and time). This holds true for time-space movements both in the short (i.e., day) and long (i.e., life) time perspectives. Hägerstrand's early studies of time-space movements over the lifetime of individuals in the population of Asby parish were formative for his later scientific endeavor and laid the ground for the time-geographical concept individual path (trajectory).

4.2 Daily activities performed at different places - the base for activity-oriented transportation research

The short time span in Hägerstrand's thinking is often exemplified by a day. One reason is that the daily activity rhythm of human individuals is restricted by the need for sleep and that people usually return to their home to sleep. He wrote:

"Human beings as well as many animals have a nest, a base where they sleep and to which they return after shorter or longer excursions into surrounding areas. This return principle is a constraint, strongly influencing which projects an individual can participate in and for how long. As a consequence, the same principle regulates the organization of a society as a whole in several fundamental ways." (Hägerstrand, 1985, p. 206).

With the principle of return as point of departure, Hägerstrand presented the concept of a prism. It is that part of the total time-space that is within future reach of an individual during the period of the day when she can be away from her home (nest) (Hägerstrand, 1970; 1985). Bo Lenntorp elaborated on the concept and made considerable contributions in the further development of the time-space prism (Lenntorp, 1976). He developed a simulation model useful for trying various organizations of transportation in cities. Many researchers have followed this line of time-geographic transportation research (Persson and Ellegård, in press).

Hägerstrand's private experiences in the organization of public transport in the mid 1900s led him reflect on the differences between walking, biking, and going by car in relation to being a passenger on public transportation. His theoretical generalization was that while individually controlled means of transportation result in relatively simple prism configurations, "public transportation, with its less dense network of times and its time tables, produce far more complicated spaceltime caves." (Hägerstrand, 1985, p. 206). Hence, if two persons are about to perform a similar daily activity program, the person who is a passenger on public transportation most probably has to set aside more time for transportation (including waiting and changes between lines) than a person using individual means of transportation (like bike or car). Sometimes it is impossible for the public transport passenger to fulfil the activity program. This makes it difficult for the public transportation passenger to fill the daily activity program with activities located at several different places and, hence, the passenger's prism includes fewer opportunities. However, in both cases it is possible just to move 
along one single path through what was the prism of the individual when the day started (Hägerstrand, 1970).

\subsection{Non-transport focus in transport research}

Hägerstrand's writing on transport research is not basically oriented to transportation. Instead, he was interested in the life trajectories of individuals (one-by-one and interlinked in family constellations) and what was the cause and aim of movements shown by the trajectories. His early studies were on the movements of the population in Asby parish, both long-distance emigration from Sweden to the United States and shorter movements of families from one dwelling to another within the parish. In later studies, he was interested in people's daily movements, such as how they moved at the workplace, bought food in the grocery shop, and left to pick up children at the nursery school (Hägerstrand, 1970; 1985; Ellegård et al., 1977). Hence, in Hägerstrand's time-geographic approach, geographical movements are of secondary importance: someone wants to leave some place in order to encounter another place to be-in-place and do something. Then, the time-geographical notation system underlines the importance of being stationary somewhere to perform activities bound to that place. This phenomenon is seldom taken into consideration in transport geography since nothing seems to happen when being-in-place. However, even if the location is the same, time goes by and activities are performed for a time at one place. Movements between places, then, are seen as links, binding activities together into a sequence that has meaning for the individual. The time-geographical notation system offers opportunities to describe any of the time-space of movements in a similar way, irrespective of scale and the type of individual it concerns (Hägerstrand, 1974).

Hägerstrand dealt with problems of the increasing need for longer transports in the mid twentieth century. The spread of diseases is an example of problematic side effects of air transportation that were alluded to previously (section 2.7). In the 1950s and 1960s domestic Swedish transport planning was mostly related to the need for roads and how to control traffic flows of traffic (Hägerstrand, 1993a). He opposed the organization of territorially bounded, local, and specialized planning agencies, since they could not take into consideration either the reasons for the increasing lengths of transport flows generated by modern industries and the increasing motorism, nor the starting points of the transports or where they should end. This reasoning is parallel to his path-breaking conclusions from the studies of what happened in Asby parish when the emigrants left: It was not primarily a question of the number of people in movement flows or of the number of vacant houses, but a question of what made people leave their houses and emigrate or move to another house. Relevant questions, then, concerned whether there were vacancies or other opportunities for a better home and whether it was possible to move in there.

Time-geographical analyses of trajectories of individuals and the elementary events appearing in the course of the individuals' life path, prism, and constraints (authority, coupling, and capacity) provide 
multidimensional description of the time-space movements of individuals resulting from their engagement in various projects. Time-geography includes a multitude of opportunities for analysis and for explanations of transportation issues that will remain hidden to those who do not exploit the approach and ecological world view that Torsten Hägerstrand offered. Late in life, he wrote, "The intricacies of the 'choreography of existence' - to use Allan Pred's phrase - have never been seriously disentangled, thus there is no cause for being apologetic about such an attempt. I am convinced that my way of seeing reaches far beyond mere description. It offers some fundamental clues to explanation and education." (Hägerstrand, 2006, p. xii).

\section{Concluding remarks}

Throughout life, Torsten Hägerstrand combined his personal experiences with the fruits of his reading and discussions with colleagues from various scientific disciplines around the world. His work is saturated with an ambition to understand how an ecological view of the world as a whole can be conceived. It relates to the wider philosophical context drawing on classic authors who had been interested in these matters, like Goethe, Hettner, and Ratzel (Hägerstrand, 2009). He gradually developed the time-geographic approach, its notation system, and its concepts. Already in the late 1960s there was the skeleton of an approach and a world view, but many clarifications and improvements were yet to be made. Hägerstrand continued to develop concepts for elementary events in time-geography until the very end of his own life trajectory. For long, he had had to face criticism about his focus on limits and constraints. Yet, he maintained his perspective over his lifetime, and today this perspective has re-emerged in the wider scientific community as a major, important challenge in the sustainability debate, for example, on planetary boundaries and resilience thinking (Rockström et al., 2009). He also continually worked to clarify the objective of his ecological timegeographic world view; his final effort was the book The Fabric of Existence in 2009. The thoughts and themes Hägerstrand dwelt on during his life are coherent and he would return to topics while reinterpreting and developing his position. Thus, his final book expresses the results of his thinking and reflections during the last decade of his life as he synthesized his earlier thinking.

One reoccurring concern of Hägerstrand was the fragmentation of the scientific community, especially in the study of the landscape wherein all individuals exist together. Therefore, he was interested in the practical organization of the knowledge production system itself; he was deeply involved in the conditions for interdisciplinary research in Sweden and the problems encountered. He was involved, for example, in developing the thematic, interdisciplinary schools of research established by Linköping University, Sweden, in 1980.

The contribution of Torsten Hägerstrand's time-geography to transport research has its roots in his life experience without a driving license and his readings from a wide range of geographical and social research with an ecological and social basis. His question was: What are the reasons behind people's 
movements between places in the short and long time perspectives? His answer dwells in grasping everyday life as a whole by looking at the contexts in which various projects are planned to be performed, what needs for changing location they claim, and what happens to the projects when the constraints of the real world are encountered. His approach is an overt critique of the fragmentation of urban and transport planning. This can be seen as a follow-up of the previous point on Hägerstrand's critique of certain ways of doing science - in addressing the problem of over-abstraction, at the same time also stressing the need to keep a distinct degree of embedded holism as a countermeasure against disciplines that were too narrow, too specialized, or too disconnected. This general approach can also be seen as an indication of what Hägerstrand might have considered to be his message to future generations in the field of transport and mobility studies in terms of suggested methodological balancing acts.

Hägerstrand argued that many small decisions taken one-by-one and without coordination would, as an aggregate, put the life conditions of mankind at risk (Hägerstrand 1989, p. 195). He identified the risks at the global level with that kind of decision making and argued that mankind is like a natural force that has become a geological agent, by its own movements actively spreading diseases as a consequence of increasing global mobility (Hägerstrand, 1993b, p. 161). He did not argue against individual transportation means (both bicycles and fossil fuel cars are of that kind), but he was worried about the aggregate, global consequences on climate and health of the use of fossil fuel. He was concerned about the overload of cars in urban areas where other transport means and alternative activity organization could help overcome the problems. In this endeavor, Hägerstrand's ecological world view, with its coherent conceptual tools and notation system, may yet serve to increase the understanding and ecological breadth of the topic.

Now, younger researchers are encouraged to utilize the tools and concepts and to further develop Hägerstrand's ecological, time-geographic approach in order to contribute to a sustainable coexistence of individuals from different populations in the landscape - and transportation is certainly one of the most intriguing challenges in this endeavor. 


\section{References}

Buttimer, A., 1983. The practice of geography. London and New York: Longman.

Buttimer, A., 1986. Life experience as catalyst for disciplinary communication: Adventures in dialogue 1977-1985. DIA-paper. Lund: Lund University.

Carlestam, G., Sollbe, B., (Eds) 1991. Om tidens vidd och tingens ordning. Texter av Torsten Hägerstrand. (Eng. On the width of time and the order of things. Texts by Torsten Hägerstrand). Solna: Byggforskningsrådet T21:1991.

Crang, M., 2000. Between academy and popular geographies. Cartographic imaginations and the cultural landscape of Sweden. In: Cook, I., Crouch, D., Naylor S., Ryan, J. (Eds), Cultural turns/Geographical turns: Perspectives on Cultural Geography. London: Prentice Hall, pp. 88-108.

Ellegård, K., Lenntorp, B., Hägerstrand, T., 1977. Activity organization and the generation of daily travel: two future alternatives. Economic Geography, vol. 53, no 2, pp. 126-152.

Eurostat, 2003. How Europeans spend their time. Everyday life of women and men. European Commission Theme 3. Population and social conditions. Luxembourg.

Giddens, A., 1984. The constitution of society. Cambridge: Polity Press.

Haggett, P., 2000. The Geographical Structure of Epidemics. Oxford: Clarendon Press.

Hägerstrand, T., 1950. Torp och backstugor i 1800-talets Asby. (Eng. Crofts and cottages in Asby parish during the $19^{\text {th }}$ century). In: Hedkvist, E., (Ed), Från Sommabygd till Vätterstrand. Linköping: Tranås hembygdsgille, pp. 30-38.

Hägerstrand, T., 1953. Innovationsförloppet ur korologisk synpunkt. (Eng. Innovation as a Spatial Process.) Lund: Meddelanden från Lunds universitets Geografiska Institutioner 25.

Hägerstrand, T., 1955. Statistiska primäruppgifter, flygkartering och "data-processing"-maskiner. Ett kombineringsprojekt. (Eng: Statistical primary data, remote sensing and "data-processing"-machines. A project of combination) Svensk Geografisk Årsbok 1955. Lund: South-Swedish Geographical Society, pp. 233-255

Hägerstrand, T., 1962. Geographic measurements of Migration. Swedish data. In: Entretiens de Monaco en Sciences Humaines. Première Session 1962. Human displacements. Measurement Methodological Aspects. Monaco: Hachette, pp. 61-83.

Hägerstrand, T., 1965. Urbaniseringen som världsproblem. (Eng. Urbanisation as a world problem). In: Ingenjörsakademien (IVA) Meddelanden nr 139. Stadsbyggnadsfrågor, pp. 7-20

Hägerstrand, T., 1967. Innovation as a Spatial Process. Lund: CWK Gleerup, and Chicago: University of Chicago Press.

Hägerstrand, T., 1970. What about People in Regional Science? Regional Science Association Papers, Vol XXIV, pp.7-21.

Hägerstrand, T., 1972. Om en konsistent individorienterad samhällsbeskrivning för framtidsstudiebruk. (Eng: On a consistent individual level description model of society for futures 
studies) Ds Ju 1972:25. Specialarbete till SOU 1972:59. Att välja framtid. Lund - Stockholm, Justitiedepartementet.

Hägerstrand, T., Lenntorp, B., 1974. Samhällsorganisation i tidsgeografiskt perspektiv. In: SOU 1974:2, bilaga 2. Stockholm: Allmänna Förlaget, pp. 221-232.

Hägerstrand, T., 1974. Tidsgeografisk beskrivning. Syfte och postulat. (Eng: Time-geographical descriptions. Aim and postulates.) Svensk Geografisk Årsbok 50. Lund: South-Swedish Geographical Society, pp. 86-94.

Hägerstrand, T. 1976. Geography and the Study of Interaction between Nature and Society. Geoforum, Vol . 7, pp. 329-334.

Hägerstrand, T., 1977. Att skapa sammanhang i människans värld - forskningens bidrag. (Eng: To create coherence in the world of humans - the contributions from research). Kungliga vitterhets-, historie- och antikvitetsakademien. Konferenser I. Stockholm: Almqvist \& Wiksell, pp. 188-192.

Hägerstrand, T., 1978. En otidsenlig betraktelse. Attityder till tekniken. (Eng: An untimely reflection. On attitudes to technology) Stockholm: Liber/Allmänna förlaget, pp. 107-117.

Hägerstrand, T., 1982. Diorama, path and project. Tijdschrift voor Economische en Sociale Geografie 73:6, pp. 323-339.

Hägerstrand, T., 1983. In search for the sources of concepts. In: The Practice of Geography. Buttimer, A., (Ed). London: Longman, pp. 238-256.

Hägerstrand, T., 1984. Escapes from the Cage of Routines. Observations of Human Paths, Projects and Personal Scripts. In: Long, J., Hecock, R., (Eds), Leisure, Tourism and Social Change. Dunfermline College of Physical Education, pp. 7-19.

Hägerstrand, T., 1985. Time-geography: Focus on the Corporeality of Man, Society, and Environment. In: The Science and Praxis of Complexity. Tokyo: The United Nations University. pp. 193-216.

Hägerstrand, T., 1989. Globalt och lokalt. (Eng: Global and local) Svensk Geografisk Årsbok vol 65, 1989. Lund: South-Swedish Geographical Society, pp. 9-19.

Hägerstrand, T., 1993a. Om boendekunskap: Vår roll är förvaltarens, inte exploatörens. (Eng: On knowledge about living in houses: Our role is the custodian - not the exploiter). In: Planera för en bärkraftig utveckling. Kullinger, B., Strömberg, U-B., (Eds). Solna: Byggforskningsrådet, pp. 207217.

Hägerstrand, T., 1993b. What about Nature in Regional Science? In: Visons and Strategies in European Integration. A North European Perspective. Lundqvist, L., Persson, L. O. (Eds.) Berlin Heidelberg: Springer-Verlag, pp. 155-161.

Hägerstrand, T., Lenntorp, B., 1993. Region och miljö - sammanfattning av ett projekt om ekologiska perspektiv på den rumsliga närings- och bosättningsstrukturen. (Eng. Region and environment - a summary of a project about ecological perspectives on the spatial structure industry and settlements). NordREFO 1993:5. Stockholm: Nordiska arbetsgruppen för regionalpolitisk forskning, pp. 229-237.

Hägerstrand, T., 2004. The two vistas. Geografiska Annaler 86 B, no 4, pp. 315-323. 
Hägerstrand, T., 2006. Foreword by Torsten Hägerstrand. In: Buttimer, A., Mels, T., (Eds) By northern lights: on making of geography in Sweden. Ashgate Publishing Group, pp. xi-xiv.

Hägerstrand, T. 2009. Tillvaroväven. (Eng. The fabric of existence). Ellegård, K., Svedin, U., (Eds.). Stockholm: Formas.

Kwan, M. P. 2004. GIS methods in time-geographic research: Geocomputation and geovizualisation of human activity patterns. Geografiska Annaler, Series B, Human Geography 86, (4), pp. 267-280.

Lagerlöf, S., 1906/07. Nils Holgerssons underbara resa genom Sverige. Stockholm: Bonniers.

Lenntorp, B., 1976. Paths in space-time environments: a time-geographic study of movement possibilities of individuals. Lund Studies in geography, Series B, Human geography 44. Lund: Liber Läromedel/Gleerup.

Mårtensson, S., 1979. On the formation of biographies in space-time environments. Lund Studies in Geography, Series B, Human Geography 47. Lund: Lund University, Department of Geography.

Persson, O., Ellegård, K., in press. Torsten Hägerstrand in the Citation Time Web. The Professional Geographer. (Available online: 25 Aug 2011) Online link:

http://dx.doi.org/10.1080/00330124.2011.601187)

Rockström, J., Steffen, W., Noone, K., Persson, Å., Chapin, III, F.S., Lambin, E.F., Lenton, T.M., Scheffer, M., Folke, C., Schellnhuber, H.J., Nykvist, B., de Wit, C.A., Hughes, T., van der Leeuw, S., Rodhe, H., Sörlin, S., Snyder, P.K., Costanza, R., Svedin, U., Falkenmark, M., Karlberg, L., Corell, R.W., Fabry, V.J., Hansen, J., Walker, B., Liverman, D., Richardson K., Crutzen P., Foley, J., (2009). A safe operating space for humanity. Nature 461: 472-475.

Rystedt, B., 2005. Introduction to Hägerstrand, T., Statistiska primäruppgifter, flygkartering och "data-processing"-maskiner. Ett kombineringsprojekt. First publ. in 1955. Mapping and image Science 2005:2. Gävle: Kartografiska sällskapet (Swedish Cartographic Society), pp. 69-71. 